\title{
ПСИХОЛОГІЧНА ПІДГОТОВКА ВИКЛАДАЧІВ ЯК УМОВА ГУМАНІЗАЦІЇ ВІДНОСИН ВИКЛАДАЧ-СТУДЕНТ
}

Т. В. Налужна

\author{
Державний вищий навчальний заклад \\ “Івано-Франківський національний медичний університет”
}

\section{PSYCHOLOGICAL TRAINING OF TEACHERS AS A CONDITION OF HUMANIZATION RELATIONSHIP TEACHER-STUDENT}

\author{
State Higher Educational Institution \\ "Ivano-Frankivsk National Medical University"
}

\begin{abstract}
У статті проаналізована проблема формування нового типу гуманних, партнерських відносин між викладачем і студентом, що передбачає їх свободу та творчий пошук. Доведено, що реалізація цісї проблеми можлива лише за умови обов'язкової психологічної підготовленості викладачів до якісно нової організації їх діяльності.
\end{abstract}

The article analyzes the problem of forming of a new type of humanistic, partnership relations between a teacher and a student, that provides their freedom and creativity. It is proved that the implementation of this problem is possible only with mandatory psychological preparedness of teachers to a qualitatively new organization of their activities.

Вступ. Соціально-економічні процеси, які відбуваються в Україні, з особливою гостротою ставлять проблему підготовки педагогічних кадрів, здатних реалізувати головне завдання демократичної держави - формування свідомого громадянина, освіченої і творчої особистості, фізичної та морально здорової людини, яка може відтворити і трансформувати культуру й духовність в усій різноманітності вітчизняних та світових зразків.

Освітня галузь України за всіма напрямами вимог Болонської декларації потребує гуманізації. Перше і найбільш вагоме завдання - це вироблення і впровадження нової філософії освітньої діяльності, формулювання і виконання нових принципів організації навчального процесу, це нові “технологіі” опанування знань, новий тип відносин між викладачем і студентом. Реалізація цих завдань можлива лише за умови обов'язкової психологічної підготовленості викладачів.

Основна частина. У нових умовах демократизації українського суспільства, коли роль самостійної творчої людини гостро зростає, орієнтація та формування автономної та суверенної особистості, висококваліфікованого спеціаліста, сприйняття іншої людини як цінності, гуманізація відносин викладач-студент стає головним напрямом перебудови освіти на якісно новій основі.
Праця викладача, незалежно від його рівня, вимагає, з одного боку, професійної компетентності: знань та умінь; а з іншого - соціально-психологічної компетентності: знань у галузі психології особистості, колективу, спілкування, управління та уміння розуміти себе та інших. У сучасних умовах актуальною стає саме психологічна підготовка викладачів вищих медичних закладів, яка дозволить їм не тільки використовувати знання та ідеї з медичних дисциплін для вирішення практичних питань у професійній діяльності, а й допоможе розвинути в собі соціально значимі якості особистості.

Аналіз опрацьованоїлітератури, індивідуальні бесіди зі студентами та викладачами, проведення кураторських годин дозволили скласти психологічний портрет сучасного викладача та визначити якості, які забезпечують успішність виконання професійноїдіяльності. Ці якості можна умовно поділити на такі категорії:

- психічні процеси (добре розвинена пам'ять, високий рівень розподілу уваги, аналітичне, творче мислення, креативність), психічні стани та психологічні особливості;

- психічні стани (психічна та емоційна урівноваженість);

- психологічні особливості (організаторські здібності, ораторські здібності, комунікативні здібності, здатність до співчуття ) [1]. 
Мистецтво спілкування завжди вважалося органічною складовою професіоналізму викладача, який повинен мати нестандартний погляд, володіти самостійним аналітичним мисленням, відзначатися етикою у спілкуванні, мати дар вести за собою колектив не силою наказів чи влади, а силою аргументів і переконуючого слова. Спілкування викладача і студента потребує від викладача певних навичок і вмінь. А саме: уміння слухати та говорити; переконувати та наказувати; давати пораду; впливати на вихованців; управляти груповою діяльністю; активізовувати думку, мислення в процесі навчальної діяльності; допомагати приймати рішення тощо.

У спілкуванні викладача і студента подекуди виникають труднощі, причинами яких, на нашу думку, $є$ недостатня обізнаність студентів або ж завищена у них самооцінка, низький рівень культури спілкування, а у викладачів - небажання або невміння зрозуміти студентів, апатія до них або ж поганий настрій.

Гуманістичний підхід викладача у спілкуванні визначається тим, що воно не можливе без взаємного визначення свободи і унікальності, гідності та суверенності тих, хто спілкується.

Найскладнішою проблемою гуманізації стосунків між викладачем і студентом залишається методична робота з формування етико-педагогічних навичок спілкування. Викладача (за фахом медика) потрібно практично вчити, як встановлювати мовний, візуальний, тактичний контакт з особистістю; створювати ситуації успіху “авансованої довіри”, оцінки; демократизувати стосунки. Викладач повинен вміти встановлювати особливий тип взаємовідносин, який сприяє розвитку і розкриттю наявних та потенційних можливостей студента.

У педагогіці такий тип взаємовідносин прийнято називати “партнерським”, “діалогічним”, “суб'єкт суб' єктивним” і таким, що за своєю суттю опирається на засади гуманістичної психології. Основу цих стосунків складають “безоціночне сприйняття” партнерів по спілкуванню, що виявляється в неупередженості та руйнації існуючих стереотипів, “емпатійній підтримці” або ж умінні розуміти психічний стан співбесідника та здатності вирішувати проблеми конструктивним способом, “довірі до власних почуттів” як необхідній умові збереження власної індивідуальності та відкритості у спілкуванні.

Гуманістична парадигма взаємовідносин передбачає свободу та творчий пошук як студентів, так i викладачів-педагогів.

Основною умовою складання як власної стратегії руху на шляху пошуку найбільш ефективних способів педагогічної діяльності, так і прогнозування руху студента в освітньому просторі є розвиток критичного, рефлексивного мислення викладача [2].

Відмінною особливістю навчального процесу в умовах кредитно-модульної системи є фактичне “авторство” викладача в процесі розробки та викладання дисципліни. Неможливо запозичити "чужий" досвід 3 цього питання у готовому вигляді для користування. Він повинен бути адаптованим як до умов вищого навчального закладу в цілому, виходячи із його специфіки, так й індивідуальності самого викладача.

Формуванню рефлексивних здібностей сприяє відповідна організація “рефлексивного середовища" в процесі підготовки викладачів до інноваційної діяльності. У нашому університеті процес підготовки суб' єктів педагогічного процесу до діяльності в умовах кредитно-модульної системи навчання відбувається під час проведення психолого-педагогічного семінару, де здійснюється медіаосвітнє навчання викладачів, проводяться рефлексивні ігрові тренінги, що сприяють інтенсифікації процесів самовизначення, самопізнання та самоактуалізації особистості. Включення викладача в ряд проблемно-конфліктних і критично-формуючих ситуацій, в яких він виявляє себе як цілісний суб' єкт на перехресті соціальних та особистісних позицій, помітно сприяє його професійному розвитку.

На нашу думку, необхідно розробити і ввести до навчального плану психолого-педагогічного семінару курс "Педагогічна деонтологія", який би чітко визначив правила і норми поведінки педагога у сфері його професійної діяльності, заклав основи для конструювання орієнтирів рефлексивної професійно-оціночної поведінки викладача.

Цей курс передбачає теоретичне і практичне оволодіння молодим викладачем без педагогічної освіти засадами психолого-педагогічної культури, розвиток особистісних якостей педагога, розуміння особливостей свого морального статусу. Курс передбачає передусім формування моральних цінностей педагогічної професії через засвоєння ії нормативних засад. Етичні цінності розглядаються як багатоаспектне утворення, різні сторони якого стимулюють особистісний, професійний розвиток людини на всіх рівнях. Головними завданнями курсу $є$ : вивчення принципів, норм і правил професійної поведінки викладача; формування, регулювання і оцінювання професійної поведінки та діяльності педагогів; визначення професійно важливих якостей педагога-викладача, які мають моральну природу; дослідження системи зовнішніх і внутрішніх факторів, що визначають по- 
ведінку викладача; вивчення співвідношення структури особистості з вимогами до іiї професійної діяльності; визначення і аналіз типових помилок педагогічної поведінки, пов'язаних 3 недотриманням норм педагогічної моралі; виявлення несприятливих чинників і негативних наслідків, помилкових, афектних дій у педагогічній діяльності [6].

Загалом, аналіз педагогічної літератури [1 - 7] свідчить про те, що у становленні викладача вищого навчального медичного закладу як професіонала виявляються різною мірою суперечливі тенденції, а саме:

- між саморозвитком і самозбереженням: саморозвиток вимагає інтенсивно вкладати всі сили і прискорювати професійний ріст, а самозбереження диктує необхідність розраховувати сили на всю траєкторію життєвого шляху;

- між результатами і процесом праці: результативний підхід вимагає залучення всіх і будь-яких засобів; процесуальні критерії звертають увагу тих, що навчаються, на необхідність вибірковості й педантичності при виборі засобів, особливо в професіях типу “людина-людина" - педагогічної діяльності; мета не завжди виправдовує засоби, мету можна досягати не будь-яким шляхом, вибір засобів коректується професійною етикою. 3 названим вище явищем пов'язаний незбіг об'єктивного результату і його психологічної цінності для людини;

- незбіг у ряді випадків предметних, соціальних еталонів, норм праці з індивідуальними нормами і критеріями. Професія викладача вимагає виконання прийнятих туг правил праці іпрофесійного середовища, іноді жертв, віддачі всіх людських сил, особистого часу, а внутрішні оцінки людини підказують йому важливість співвіднесення своїх можливостей з непосильними завданнями. Індивідуальні здібності, домагання викладача можуть провокувати його або випереджати прийняті в педагогічній діяльності норми або не рахуватися з ними і активно боротися за свої індивідуальні еталони та критерії ефективності праці;

- неузгодженість становлення різних видів компетентності (спеціальної, соціальної, особистісної, індивідуальної). Професійна компетентність (майстерність, знання справи) у конкретного викладача може далеко випереджати соціальну (уміння спілкуватися), особистісну (уміння цілеспрямовано розвивати себе) та ін.;

- розузгодження темпів розвитку в окремих викладачів мотиваційної і операційної сфер педагогічної діяльності, коли наявність високого професіоналізму в аспекті володіння новими технологіями не підкріпляється зрілою мотиваційною сферою;
- різна роль і міра вираження процесів розвитку $і$ компенсації у різних викладачів, а також в одного, але на різних етапах. Так, недолік досвіду може компенсуватися життєвими силами, одержимістю намірів, а у міру старіння згасання життєвих сил, зниження психічних функцій компенсуються пристосувальними прийомами для підтримки і навіть посилення ефективності діяльності;

- нерівномірність освоєння окремих дій і цілісної структури педагогічної діяльності, професійно важливих якостей, що виражається в мінливості показників ефективності, немонотонностіїх ростуна різних етапах освоєння цього виду діяльності, наявності періодів згасання успішності, відносного застою і навіть регресу, а також у нерівномірності розвитку професійно важливих якостей, що реалізовують педагогічну діяльність - спочатку ефективність залежить від професійно важливих якостей і інших здібностей, але у міру освоєння педагогічної діяльності вона стимулює розвиток педагогічних здібностей, вимагає великих можливостей і більш високих рівнів професійно важливих якостей;

- зіставлення у свідомості викладача між прагненням до вузької спеціалізації іпотребою упізнавати щось про суміжні професії, оволодіти близькими спеціальностями, бути універсалом;

- незбіг інколи виявів у одного і того ж викладача психічних якостей у професійній і непрофесійній сфеpax;

- неузгодженість ціннісного ставлення до себе в праці і до цього виду праці в собі.

Отже, все сказане дозволяє зробити висновок, що ігнорування подібних суперечливих тенденцій у розвитку окремого викладача може привести до професійних криз, збоїв, зупинок у розвитку. Тому кожному педагогу важливо усвідомлювати суперечності у своєму професійному розвитку, щоб вчасно знаходити з них конструктивний вихід [7].

Позиція викладача в умовах інноваційної освіти стає управлінською. Студент і студентська група виступають об'єктами управлінської діяльності викладача, i вирішення ними навчальних завдань та досягнення поставлених цілей можливо лише за умов відповідних управлінських дій, а саме: вмілого планування навчальної діяльності, організації процесу навчання і виховання, вмілого внутрішнього спонукання студента до високоефективної аудиторної та позааудиторної роботи та об' єктивного способу оцінювання результатів навчальної діяльності студентів.

Система взаємодії викладача і студента повинна бути зрозумілою, чіткою і прозорою. Звернення ува- 
ги на цей аспект діяльності викладача зумовлений необхідністю перебудови традиційних форм, методів навчання у вищій школі, а особливо способів оцінювання його результатів. Запровадження модульнорейтингової технології навчання у вищих навчальних закладах зумовило появу різних систем оцінювання. Як показує практика, часто вони є не сповна виважені самими викладачами, що примушує його в процесі роботи підганяти результати оцінювання до відповідної системи балів, рейтингів тощо. У свою чергу, така непідготовленість зумовлює високе психологічне напруження, роздратування, нервозність, що потім змінюється апатією та байдужістю студента. За таких умов мета, на яку спрямовані інноваційні зміни у вузі, часто може замінитися псевдометою, зокрема, необхідність у розвитку самостійності студента може

\section{Література}

1. Давиденко Н. В. Доцільність тренінгових технологій у галузевому вищому навчальному закладі / Н. В. Давиденко, I. О. Петухова // Проблеми гуманізації навчання та виховання у вищому закладі освіти : матеріали Третіх Ірпінських міжнародних науково-педагогічних читань. Ірпінь : Національна академія ДПС України, 2005. - С. 445.

2. Чуйко О. В. Психологічна підготовка викладачів до діяльності в умовах інноваційної освіти / О. В. Чуйко // Проблеми гуманізації навчання та виховання у вищому закладі освіти : матеріали Третіх Ірпінських міжнародних науковопедагогічних читань. - Ірпінь : Національна академія ДПС України, 2005. - С. 493.

3. Моляко В. О. Психологія творчості - нова парадигма дослідження конструктивної діяльності людини / В. О. Моляко // Практична психологія та соціальна робота. - 2004. - трансформуватися у головну мету - звільнення студента від екзамену за хорошу успішність упродовж семестру.

Висновки: 1. Проаналізовані аспекти психологічної підготовки викладачів вищих медичних навчальних закладів до інноваційних процесів повинні бути предметом уваги керівників різного рівня вищого медичного навчального закладу.

2. Серед перспектив подалыших розвідок гуманізації відносин викладач - студент повинні бути розробка методичних рекомендацій щодо формування етикопедагогічних навичок спілкування та підвищення компетентності, професіоналізму викладацького складу вищих медичних навчальних закладів, а також виявлення оптимальних шляхів формування у викладачів відповідної мотивації до професійної самореалізації.

\section{№ 8. - С. 1-4.}

4. Фрейре П. Педагогіка свободи: етика, демократія і громадянська мужність / П. Фрейре. - К. : КМ Академія, 2004. $-122 \mathrm{c}$.

5. Коротяєв Б. І. Педагогіка вищої школи / Б. І. Коротяєв, Е. О. Гришин, О. А. Устенко. - К., 1990. - 128 с.

6. Хоружа Л. Курс "Педагогічна деонтологія" у системі професійної підготовки сучасного вчителя / Л. Хоружа // Освіта і управління. - 2003. - Т. 6, № 3. - С. 133-136.

7. Сіцінський А. С. Професіоналізм викладацького складу вищої школи як проблемне питання / А. С. Сіцінський, Л. М. Мотозюк // Проблеми гуманізації навчання та виховання у вищому закладі освіти : матеріали Третіх Ірпінських міжнародних науково-педагогічних читань. - Ірпінь : Національна академія ДПС України, 2005. - С. 486-488. 